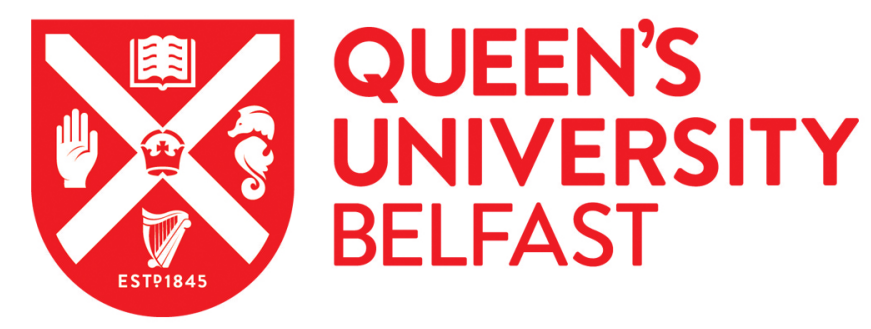

\title{
Biological mobilization of potassium from clay minerals by ectomycorrhizal fungi and eucalypt seedling roots
}

Yuan, L., Huang, J. G., Li, X. L., \& Christie, P. (2004). Biological mobilization of potassium from clay minerals by ectomycorrhizal fungi and eucalypt seedling roots. Plant and Soil, 262(1-2), 351-361.

https://doi.org/10.1023/B:PLSO.0000037055.67646.97

Published in:

Plant and Soil

Queen's University Belfast - Research Portal:

Link to publication record in Queen's University Belfast Research Portal

\section{General rights}

Copyright for the publications made accessible via the Queen's University Belfast Research Portal is retained by the author(s) and / or other copyright owners and it is a condition of accessing these publications that users recognise and abide by the legal requirements associated with these rights.

Take down policy

The Research Portal is Queen's institutional repository that provides access to Queen's research output. Every effort has been made to ensure that content in the Research Portal does not infringe any person's rights, or applicable UK laws. If you discover content in the Research Portal that you believe breaches copyright or violates any law, please contact openaccess@qub.ac.uk. 


\title{
Biological mobilization of potassium from clay minerals by ectomycorrhizal fungi and eucalypt seedling roots
}

\author{
Ling Yuan ${ }^{1,2}$, Jianguo Huang ${ }^{2}$, Xiaolin $\mathrm{Li}^{1,4}$ \& Peter Christie ${ }^{1,3}$ \\ ${ }^{1}$ Department of Plant Nutrition, China Agricultural University, Key Laboratory of Plant-Soil Interactions, Ministry \\ of Education, and Key Laboratory of Plant Nutrition, Ministry of Agriculture, Beijing 100094, China. ${ }^{2}$ College \\ of Resources and Environment, Southwest Agricultural University, Chongqing 400716, China. ${ }^{3}$ Agricultural \\ and Environmental Science Department, Queen's University Belfast, Newforge Lane, Belfast BT9 5PX, UK. \\ ${ }^{4}$ Corresponding author*
}

Received 10 September 2003. Accepted in revised form 10 November 2003

Key words: ectomycorrhizal fungi, Eucalyptus, phlogopite, potassium, vermiculite

\begin{abstract}
Growth, proton and oxalate efflux, $\mathrm{K}$ absorption and mineral depletion by one isolate of Cenococcum geophilum Fr., by a putative isolate of Pisolithus microcarpus and by two isolates of Pisolithus sp. were compared in pure liquid culture using either vermiculite or phlogopite as sole K source. An isolate from China (Pisolithus strain $\mathrm{XC1}$ ) showed greatest biomass and $\mathrm{K}$ accumulation from both minerals. There were inverse correlations between reduction in $\mathrm{HCl}$-extractable $\mathrm{K}$ and fungal proton efflux $(r=-0.912, P<0.001)$ and between the ratio (total $\mathrm{K}$ lost from the substrate: $\mathrm{K}$ accumulation in hyphae) and oxalate efflux $(r=-0.890, P<0.001)$. Protons effused from the fungi may have replaced interlayer $\mathrm{K}$, and oxalate effused may have led to biological weathering of the minerals, especially under conditions of limited exchangeable K with phlogopite as K source. Pisolithus sp. and Pisolithus $\mathrm{XC1}$ gave high depletion rates of $\mathrm{CH}_{3} \mathrm{COONH}_{4}$ - and $\mathrm{HCl}$-extractable $\mathrm{K}$ from the minerals and were therefore selected to study the growth and mobilization and utilization of $\mathrm{K}$ from the minerals by ectomycorrhizal eucalypt (Eucalyptus globulus Labill.) seedlings. Mycorrhizal seedlings extracted more K from the two minerals than did non-mycorrhizal controls, and those colonized by Pisolithus XC1 accumulated much more K than those inoculated with Pisolithus sp., a similar trend to fungal K accumulation in vitro. Non-mycorrhizal seedlings extracted very little $\mathrm{HF}-\mathrm{HClO}_{4}$-extractable $\mathrm{K}$ from the minerals following sequential extraction with $\mathrm{H}_{2} \mathrm{O}, \mathrm{CH}_{3} \mathrm{COONH}_{4}$ and $\mathrm{HCl}$. In contrast, mycorrhizal seedlings significantly depleted $\mathrm{K}$, although there was no difference between the two fungal strains. Patterns of depletion of sequentially extractable $\mathrm{K}$ fractions in the minerals by the fungi in pure culture in vitro differed from those exhibited by the fungus-root associations.
\end{abstract}

\section{Introduction}

The identification of nutrient uptake and mobilization mechanisms is a key issue in understanding the nutrition of ectomycorrhizal plants (Chalot et al., 2002). Ectomycorrhizal fungi cover roots and rootlets with a thick mantle of hyphae, effectively enlarging the surface areas of the roots in contact with clay minerals and soil pores that are not accessible to the root hairs (Schlecht, 1976). The finest lateral root-

*FAX No: +86-10-62891016. E-mail: lix1@cau.edu.cn lets, which can have a very short life and remain unbranched when not colonized, respond to mycorrhizal infection by growing for a longer period of time and by branching (Gerdemann, 1974), which is highly metabolism-dependent and partially related to the ion exchange between soil clay particles and roots and thus may enhance mineral nutrient uptake by plant roots. The extramatrical mycelium extending from the mantle may also play an important role in mobilization of nutrients (Smith and Read, 1997).

Numerous studies have shown that ectomycorrhizal plants extract mineral nutrients, including $\mathrm{P}$, 
$\mathrm{Ca}, \mathrm{Mg}$ and $\mathrm{K}$, from soils and minerals (Blum et al., 2002; Jongmans et al., 1997; Wallander and Wickman, 1999). Potassium, an element required in slightly lower quantities than nitrogen, is one of the essential major nutrients for trees in forests. Forest trees deficient in $\mathrm{K}$ are commonly found in subtropical and tropical acid soils, and ectomycorrhizal inoculation might improve the growth and $\mathrm{K}$ nutrition of the trees in artificial plantations in those areas. Huang and Lapeyrie (1996) reported the utilization of $\mathrm{HCl}$-extractable $\mathrm{K}$ by Douglas fir inoculated with Laccaria bicolor S238N and the concomitant acceleration of tree growth rate. Similarly, the growth of Pinus sylvestris seedlings was stimulated by Paxillus involutus when microcline was used as the K source (Wallander and Wickman, 1999). Moreover, simultaneous depletion of $\mathrm{K}$ and $\mathrm{Mg}$ in culture media leads to weathering of phlogopite by ectomycorrhizal fungi. This biological weathering, resulting in the release of otherwise unavailable $\mathrm{K}$ from minerals, seems to be related to the efflux of oxalate ions and protons by hyphae because Lapeyrie et al. (1987) have reported that the weathering of the minerals is promoted by oxalate, and the interlayer $\mathrm{K}$ in $2: 1$ clay minerals can be replaced by protons. Wallander and Wickman (1999) also found higher concentrations of citric and oxalic acids in solutions from media containing biotite that were used to grow pine seedlings colonized by Suillus variegatus. Thus, release of organic acids may be a mechanism by which ectomycorrhizas mobilize and then absorb unavailable $\mathrm{K}$ from soils. However, there is still no direct evidence for the exploitation by ectomycorrhizas of soil $\mathrm{K}$ pools that are unavailable to non-mycorrhizal plants.

Analysis of $\mathrm{K}$ concentrations in plant tissues has also failed to demonstrate unequivocally the involvement of ectomycorrhizas in soil $\mathrm{K}$ uptake and mobilization. Following ectomycorrhizal inoculation, promotion of $\mathrm{K}$ uptake by host trees from soils has been found, but in some cases $\mathrm{K}$ has been found to be at a lower concentrations in the tissues of plants inoculated with mycorrhizal fungi compared to uninoculated controls (Bowen, 1973; Smith and Read, 1997). This may be due to a dilution effect resulting from mycorrhizal stimulation of host plant growth and suggests that $\mathrm{K}$ uptake is a better indicator than $\mathrm{K}$ concentration of mycorrhizal effects on plant $\mathrm{K}$ nutrition. Fungal species have been shown to vary in their capacity to enhance the growth and nutrition of host plants (Bowen, 1973; Huang and Lapeyrie, 1996; Smith and Read, 1997). Among 16 ectomycorrhizal fungi studied by Burgess et al. (1993), only four (includ- ing Pisolithus sp. in the present study and formerly Pisolithus tinctorius 2144) promoted the growth and P uptake of eucalypt seedlings. There are several possible explanations for these variable results, including the limited number of tree and fungal species (and especially fungus-root associations) that have been studied. The influence of host plant roots in symbiosis on fungal nutrient absorption and utilization should not be neglected. Furthermore, interference from confounding factors that influence nutrient mobilization and absorption by trees under field conditions such as soil type, soil available nutrient concentrations and age of trees, should be taken into consideration.

Biological weathering of phlogopite and vermiculite by ectomycorrhizal fungi was further studied in vitro by Paris et al. (1995a,b; 1996). Enhanced weathering of phlogopite by $P$. tinctorius 441 (now a putative strain of $P$. microcarpus according to Martin et al., 2002) under conditions of $\mathrm{K}^{+}$and $\mathrm{Mg}^{2+}$ depletion was found to be associated with specific $\mathrm{Al}^{3+}$ immobilization (Paris et al., 1995a), and the fungus accumulated oxalic acid when supplied with either $\mathrm{NH}_{4}^{+}-\mathrm{N}$ or $\mathrm{NO}_{3}^{-}-\mathrm{N}$, although Paxillus involutus accumulated oxalate only on $\mathrm{NO}_{3}^{-}-\mathrm{N}$ (Paris et al., 1996). Oxalic acid also appeared to be involved in vermiculite weathering by Paxillus involutus and the presence or absence of soluble $\mathrm{NH}_{4}^{+}$or Ca did not appear to affect fungal immobilization potential (Paris et al., 1995b).

Cation mobilization and mineral weathering has yet to be evaluated in mycorrhizal associations. It is thus important to study the utilization and mobilization of $\mathrm{K}$ from clay minerals by ectomycorrhizas formed by various fungal species with the host tree. The aim of the present study was to complement the work of Paris et al. (1995a,b; 1996) by evaluating further the capacity of several ectomycorrhizal fungal isolates to mobilize and then utilize $\mathrm{K}$ pools in $2: 1$ type clay minerals in vitro and to examine the fractions of $\mathrm{K}$ removed from the minerals using a sequential extraction procedure, and to extend the study to ectomycorrhizal plants by comparing the effects of two of the fungal strains on $\mathrm{K}$ mobilization and absorption by a eucalypt host species. 


\section{Materials and methods}

Biological mobilization of $K$ from clay minerals by ectomycorrhizal fungi in vitro

\section{Fungal strains}

Three of the ectomycorrhizal fungi used in the experiments, namely Cenococcum geophilum SIV, a putative isolate of Pisolithus microcarpus formerly referred to as P. tinctorius 441 (Martin et al., 2002) and Pisolithus sp. (previously P. tinctorius 2144) were provided by Dr Frédéric Lapeyrie of the Centre de Recherches Forestières de Nancy in France, and Pisolithus XC1 was obtained from the Microbiology Laboratory, Southwest Agricultural University, Chongqing, China. The putative isolate of $P$. microcarpus was originally isolated in Brazil, Pisolithus sp. in Australia and Pisolithus XC1 from Xichang, Sichuan province, China (all from mycorrhizal Eucalyptus spp.), and C. geophilum SIV was originally isolated from spruce mycorrhizas in Europe. Mycelium for inoculation was grown on Pachlewski agar medium for three weeks. The medium contained $0.5 \mathrm{~g} \mathrm{~L}^{-1}$ tartrate, $1.0 \mathrm{~g} \mathrm{~L}^{-1} \mathrm{KH}_{2} \mathrm{PO}_{4}$, $0.5 \mathrm{~g} \mathrm{~L}^{-1} \mathrm{MgSO}_{4}, 20 \mathrm{~g} \mathrm{~L}^{-1}$ glucose, $5.0 \mathrm{~g} \mathrm{~L}^{-1}$ maltose, $0.1 \mathrm{~g} \mathrm{~L}^{-1}$ vitamin $\mathrm{B}_{1}, 20 \mathrm{~g} \mathrm{~L}^{-1}$ agar and $1 \mathrm{~mL} \mathrm{~L}^{-1}$ microelement solution $(1 \mathrm{~L}$ microelement solution contained $8.45 \mathrm{mg} \mathrm{H}_{3} \mathrm{BO}_{3}, 5 \mathrm{mg} \mathrm{MnSO}_{4}$, $6 \mathrm{mg} \mathrm{FeSO}$, $0.625 \mathrm{mg} \mathrm{CuSO}_{4}, 2.27 \mathrm{mg} \mathrm{ZnCl}_{2}$ and $\left.0.27 \mathrm{mg}\left(\mathrm{NH}_{4}\right)_{2} \mathrm{MoO}_{4}\right)$.

\section{Preparation of the minerals}

Phlogopite and vermiculite were collected from Jinchen Mine, Sichuan province, China $\left(31^{\circ} 52^{\prime} \mathrm{N}\right.$, $\left.103^{\circ} 55^{\prime} \mathrm{E}\right)$. They were air-dried and ground to pass a $0.1-\mathrm{mm}$ sieve. Vermiculite was then saturated with $0.1 \mathrm{~mol} \mathrm{~L}^{-1} \mathrm{KCl}$ for one week. The $\mathrm{KCl}$-saturated vermiculite was then washed with deionized water several times to remove water-soluble $\mathrm{K}$. The sizes of various $\mathrm{K}$ pools in phlogopite and $\mathrm{K}$-saturated vermiculite after sterilization are shown in Table 1.

\section{Experimental procedure}

Pachlewski liquid medium was prepared in which the $\mathrm{KH}_{2} \mathrm{PO}_{4}$ was replaced by $\mathrm{NaH}_{2} \mathrm{PO}_{4}$ with an equivalent amount of phosphorus. Aliquots $(20 \mathrm{~mL})$ of the liquid medium were transferred into $100-\mathrm{mL}$ Erlenmeyer flasks with $0.500 \mathrm{~g}$ phlogopite or vermiculite added as $\mathrm{K}$ source. After steam-sterilization at $121^{\circ} \mathrm{C}$ for 30 min each flask was inoculated with a plug of mycelium $5 \mathrm{~mm}$ in diameter. Blank control flasks were set up in the same way but with no inoculation. The flasks were incubated for 3 weeks at $25 \pm 1{ }^{\circ} \mathrm{C}$ in the dark. There were 12 replicates of each treatment.

\section{Sampling and analysis}

The fungi were harvested and washed with deionized water to remove culture medium from the surface of the mycelium. They were then oven-dried, weighed and digested with $\mathrm{H}_{2} \mathrm{SO}_{4}-\mathrm{H}_{2} \mathrm{O}_{2}$.

The culture solutions together with minerals were centrifuged at $4500 \mathrm{rpm}$ for $10 \mathrm{~min}$ to separate the minerals. The minerals were then air-dried and sequentially extracted with $\mathrm{H}_{2} \mathrm{O}$ and $1 \mathrm{~mol} \mathrm{\textrm {L } ^ { - 1 }}$ $\mathrm{CH}_{3} \mathrm{COONH}_{4}$ by shaking at $150 \mathrm{rpm}$ under $30{ }^{\circ} \mathrm{C}$ for $30 \mathrm{~min}$, and with $1 \mathrm{~mol} \mathrm{~L}^{-1} \mathrm{HCl}$ with boiling for $10 \mathrm{~min}$ (mineral:solution ratio $=1: 10$ ).

The culture solutions were analysed at harvest for $\mathrm{pH}$ using a $\mathrm{pH}$ meter and for oxalate by a $\mathrm{KMnO}_{4}$ titration procedure following precipitation with saturated $\mathrm{Ca}(\mathrm{OH})_{2}$ solution as $\mathrm{CaC}_{2} \mathrm{O}_{4}$ and dissolution with $\mathrm{H}_{2} \mathrm{SO}_{4}$ (Peng et al., 1985). The concentration of $\mathrm{K}$ in the digests, extracts and liquid media was determined by flame photometry.

\section{Biological mobilization of $K$ from clay minerals by ectomycorrhizal eucalypt seedlings}

\section{Preparation of ectomycorrhizal seedlings}

On the basis of their capacities to deplete $\mathrm{K}$ pools in the two minerals in the experiment described above, Pisolithus sp. and Pisolithus XC1 were selected for inoculation of eucalypt seedlings for further study and were grown on Pachlewski agar medium. Eight mycelial plugs (each $5 \mathrm{~mm}$ in diameter) were inoculated in a row at the centre of one half of each $12-\mathrm{cm}-$ diameter culture plate containing $20 \mathrm{~mL}$ Pachewski agar medium from which all maltose and $95 \%$ of the glucose were omitted. Following cultivation at $25^{\circ} \mathrm{C}$ for two weeks, $20-25 \mathrm{CaClO}_{3}$-sterilized seeds of E. globulus were sown in a line parallel with, and about $10 \mathrm{~mm}$ away from, the row of fungal colonies. The culture plates were then inclined with the seed row positioned horizontally above the mycelial row and cultured at $25^{\circ} \mathrm{C}$ with a light intensity of 10000 lux for a further two weeks. Fungus-root associations were formed as the roots grew downwards and made contact with the fungal hyphae. Non-mycorrhizal seedlings were produced in the same way except that no fungal mycelia were grown in the plates. 
Table 1. Analysis of potassium pools in the two minerals by sequential extraction

\begin{tabular}{|c|c|c|c|c|}
\hline \multirow[t]{2}{*}{ Clay or mica mineral } & $\mathrm{H}_{2} \mathrm{O}-\mathrm{K}^{+}$ & $\mathrm{CH}_{3} \mathrm{COONH}_{4}-\mathrm{K}^{+}$ & $\mathrm{HCl}-\mathrm{K}^{+}$ & \multirow{2}{*}{$\begin{array}{l}\mathrm{HF}-\mathrm{HClO}_{4}-\mathrm{K}^{+} \\
\left(\mathrm{mg} \mathrm{g}^{-1}\right)\end{array}$} \\
\hline & \multicolumn{3}{|c|}{$\left(\mu \mathrm{g} \mathrm{g}^{-1}\right)$} & \\
\hline Vermiculite & 5.5 & 328 & 120 & 13.0 \\
\hline Phlogopite & 2.5 & 125 & 400 & 34.5 \\
\hline
\end{tabular}

\section{Experimental design}

Quartz sand (30 g, $1 \mathrm{~mm}$ in diameter) was mixed with $2 \mathrm{~g}$ of phlogopite or vermiculite and the mixture was placed in a plastic container $6.0 \mathrm{~cm}$ in diameter and $3.0 \mathrm{~cm}$ high. The two minerals were pre-treated in the same way as described above for the in vitro experiment (Table 1). Four mycorrhizal or non-mycorrhizal seedlings were transplanted into each container. Control pots were set up in the same way without seedlings so that changes in the $\mathrm{K}$ pools in the minerals attributable to the plants could be observed. There were five replicate pots of each treatment in a fully randomized design. Seedlings were grown in a glasshouse in the summer for 60 days. Potassium-free Hoagland nutrient solution was applied daily during the growth period.

\section{Sampling and analysis}

Harvested seedlings were washed and oven-dried and then weighed. The dried seedlings were digested with $\mathrm{H}_{2} \mathrm{SO}_{4}-\mathrm{H}_{2} \mathrm{O}_{2}$. The substrate in each experimental container was air-dried. The sand was then removed and the remaining minerals in the substrate were carefully collected. The $\mathrm{K}$ fractions in the minerals were determined by sequential extraction as described above for the in vitro experiment. The residual minerals were digested with $\mathrm{HF}-\mathrm{HClO}_{4}$. The $\mathrm{K}$ concentration in the digests and extracts was determined by flame photometry.

\section{Statistical analysis}

Data were tested by two-way analysis of variance with replication (Sokal and Rolff, 1995) using the SAS package (Statsoft, 1989-1996 by SAS Institute Inc., Cary, NC, USA). Mean values for reduction in mineral $\mathrm{HCl}$-extractable $\mathrm{K}$ and fungal proton efflux, and for (total $\mathrm{K}$ lost from flask: $\mathrm{K}$ accumulation in hyphae) ratio and oxalate efflux, were compared by linear correlation with 8 degrees of freedom $(n=10)$.

\section{Results}

Biological mobilization of $K$ from clay minerals by ectomycorrhizal fungi in vitro

Fungal growth and $K$ absorption

As shown in Table 2, the four fungal isolates varied significantly in growth rate, with Pisolithus XC1 showing the highest mean biomass of about $48 \mathrm{mg}$, followed by $C$. geophilum SIV (34 mg), Pisolithus sp. $(14 \mathrm{mg})$ and $P$. microcarpus with about $7 \mathrm{mg} \mathrm{flask}^{-1}$. There was no significant difference between the two minerals in their influence on the growth of the fungi. A significant interaction between fungal isolate and clay mineral reflects the trend of slightly higher biomass of the three Pisolithus isolates grown with vermiculite compared with phlogopite and the opposite trend for C. geophilum. The three Pisolithus isolates had similar $\mathrm{K}$ concentrations irrespective of which clay mineral was the $\mathrm{K}$ source (range $13.2-15 \mathrm{~g} \mathrm{~kg}^{-1}$ ) and this was about double the concentration in C. geophilum mycelium. Potassium accumulation by the fungi, calculated by multiplying biomass by $\mathrm{K}$ concentration, followed a similar trend to fungal biomass, with Pisolithus XC1 showing the highest $\mathrm{K}$ accumulation (669 $\mu \mathrm{g} \mathrm{flask}^{-1}$ ) and $P$. microcarpus showing the lowest (94 $\mu \mathrm{g} \mathrm{flask}^{-1}$ ). Despite the vermiculite having a larger proportion of more readily available $\mathrm{P}$ than phlogopite (Table 1), there was no difference between the minerals in terms of fungal growth, $\mathrm{K}$ concentration or $\mathrm{K}$ uptake from the medium (Table 2).

\section{Efflux of protons and oxalate by fungi}

Accumulation of protons in the culture solution also varied among fungal species (Figure 1), with the highest proton accumulation in the medium of Pisolithus XC1 (21.8 $\mu \mathrm{g}$ on average) and the lowest in the P. microcarpus solution $\left(5.1 \mu \mathrm{g} \mathrm{flask}^{-1}\right)$. Proton efflux from Pisolithus isolates was unaffected by phlogopite versus vermiculite as K source but C. geophilum SIV released more protons into the medium with phlogopite compared to vermiculite (Figure 1). 
Table 2. Mean biomass, $\mathrm{K}$ concentration and $\mathrm{K}$ accumulation in fungal hyphae grown in vitro

\begin{tabular}{lllll}
\hline $\begin{array}{l}\text { Fungal } \\
\text { isolate }\end{array}$ & K source & $\begin{array}{l}\text { Biomass } \\
\left(\mathrm{mg} \mathrm{flask}^{-1}\right)\end{array}$ & $\begin{array}{l}\mathrm{K} \text { concentration } \\
\left(\mathrm{g} \mathrm{kg}^{-1} \mathrm{DW}\right)\end{array}$ & $\begin{array}{l}\mathrm{K} \text { accumulation } \\
\left(\mu \mathrm{g} \mathrm{flask}^{-1}\right)\end{array}$ \\
\hline Pisolithus XC1 & Vermiculite & 48.6 & 13.9 & 676 \\
& Phlogopite & 47.0 & 14.1 & 662 \\
Pisolithus sp. & Vermiculite & 14.1 & 15.0 & 211 \\
& Phlogopite & 13.0 & 15.3 & 199 \\
P. microcarpus & Vermiculite & 7.0 & 13.2 & 93 \\
& Phlogopite & 6.7 & 14.1 & 95 \\
C. geophilum SIV & Vermiculite & 32.4 & 7.3 & 238 \\
& Phlogopite & 34.8 & 6.5 & 227 \\
Significance ${ }^{\mathrm{a}}$ due to: & & & & $* * *$ \\
Fungus & & $* * *$ & $\mathrm{n}$ & $\mathrm{ns}$ \\
K source & & $\mathrm{ns}$ & $\mathrm{ns}$ & $\mathrm{ns}$ \\
Fungus $\times \mathrm{K}$ source & & & & \\
\hline
\end{tabular}

a By analysis of variance; ${ }^{* *}, P<0.001{ }^{* *}, P<0.01$; ns, not significant

Differences among fungal isolates in accumulation of oxalate in the culture solution followed a similar trend to proton efflux (Figure 1) with Pisolithus XC1 culture solution containing $36.6 \mu \mathrm{g}$ and P. microcarpus $18.3 \mu \mathrm{g}$ flask $^{-1}$. Phlogopite promoted oxalate efflux by Pisolithus XC1 and C. geophilum SIV, but the $\mathrm{K}$ source had no effect on oxalate accumulation in the culture solutions of the other two Pisolithus isolates.

\section{$K$ pools in residual culture medium and clay minerals}

There was more residual $\mathrm{K}$ in the culture liquid and in the $\mathrm{H}_{2} \mathrm{O}$ - and $\mathrm{NH}_{4} \mathrm{Ac}$-extractable fractions of $\mathrm{K}$ in the clay minerals when vermiculite was the sole $\mathrm{K}$ source compared with phlogopite (Table 3), and all four fungal isolates had depleted the soluble $\mathrm{K}$ in the culture medium and the $\mathrm{H}_{2} \mathrm{O}$-extractable $\mathrm{K}$ in the vermiculite. Residual vermiculite contained more $\mathrm{NH}_{4} \mathrm{Ac}$-extractable $\mathrm{K}$ than $\mathrm{HCl}$-extractable and phlogopite showed the opposite trend. Compared with control values, the fungi had depleted vermiculite $\mathrm{NH}_{4} \mathrm{Ac}$-extractable $\mathrm{K}$ in the sequence Pisolithus $\mathrm{XC1}>$ Pisolithus $\mathrm{sp} .>$ C. geophilum $\mathrm{SIV}>$ P. microcarpus. Pisolithus XC1 had also removed more $\mathrm{HCl}$-extractable $\mathrm{K}$ from vermiculite and phlogopite than the other isolates, and Pisolithus sp. had removed a relatively high proportion of this fraction. The significant interactions between fungal isolate and clay mineral indicate that $\mathrm{NH}_{4}$-extractable $\mathrm{K}$ was more depleted by the fungi in vermiculite than in phlogopite and that Pisolithus XC1 depleted HClextractable $\mathrm{K}$ from much more from both minerals than did the other fungi (Table 3).

\section{Balance between accumulation of $K$ in fungi and depletion of $K$ in substrate}

The amount of $\mathrm{K}$ lost from the substrates in the Erlenmeyer flasks, including $\mathrm{K}$ in the culture solution, and water-, $\mathrm{CH}_{3} \mathrm{COONH}_{4}$ - and $\mathrm{HCl}$-extractable fractions, was calculated from the initial amount minus that in every fraction in the flask at fungal harvest. The ratio between the summation of substrate $\mathrm{K}$ lost in each Erlenmeyer flask and $\mathrm{K}$ accumulated in fungal hyphae ranged from 0.29 to 0.78 (Figure 2) and was well below 1.00, suggesting that the fungi took up $\mathrm{K}$ from some more recalcitrant pools other than those extracted by our sequential protocol. Furthermore, Pisolithus XC1 showed a smaller ratio than the other fungi (which showed similar ratios), suggesting that Pisolithus XC1 utilized more of the recalcitrant $\mathrm{K}$ pools.

\section{Biological mobilization of $K$ from clay minerals by ectomycorrhizal eucalypt seedlings}

\section{Plant growth}

Growth of the eucalypt seedlings was promoted by fungal colonization, and plant biomass was increased more by inoculation with Pisolithus XC1 than with Pisolithus sp. (Table 4). There was also a small but sig- 


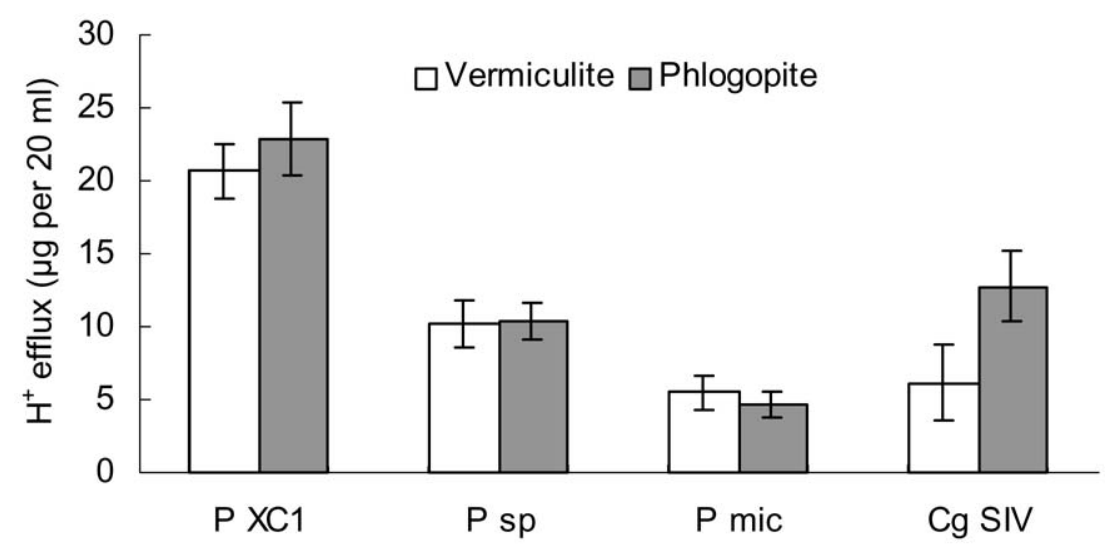

(a)

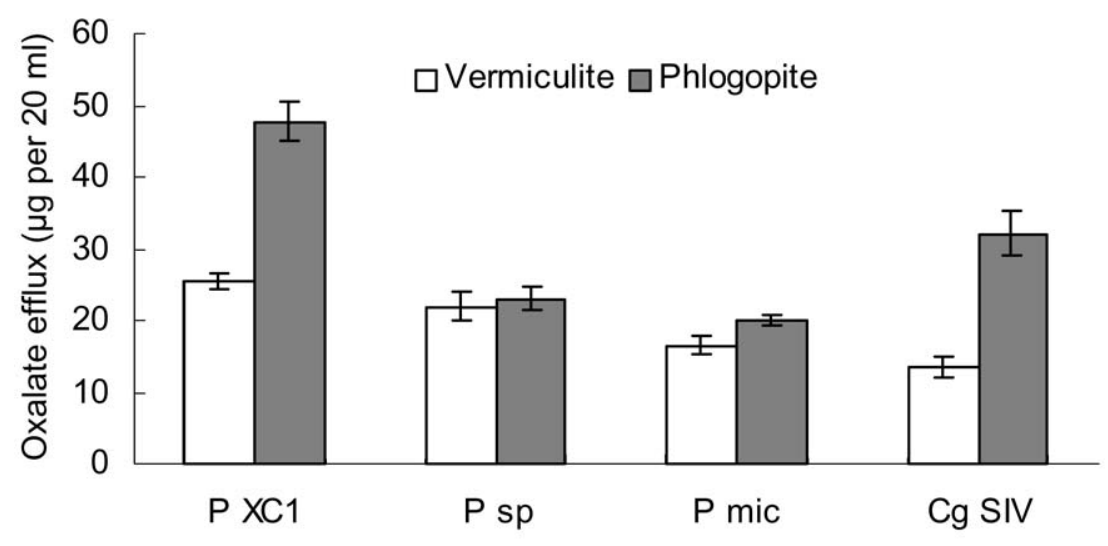

(b)

Figure 1. Mean (a) proton and (b) oxalate efflux per flask by four ectomycorrhizal fungi grown in vitro and supplied with two different minerals (vermiculite and phlogopite) as sole K source. Bars: \pm one standard deviation (SD). P XC1, Pisolithus XC1; P sp, Pisolithus sp.; P mic, putative Pisolithus microcarpus; Cg SIV, Cenococcum geophilum SIV.

nificant decrease in root:shoot ratio with mycorrhizal colonization.

\section{Seedling $K$ concentration and uptake}

There was little effect of fungal inoculation on $\mathrm{K}$ concentrations in seedling leaves, roots and stems compared with non-mycorrhizal controls except for a high concentration in the leaves of seedlings colonized by Pisolithus XC1 (Figure 3). However, the effects of fungal colonization on plant biomass were reflected in amount of K taken up by the eucalypt seedlings, with three times as much taken up by seedlings in association with Pisolithus XC1 than by non-mycorrhizal controls (Table 4).

\section{Changes in K pools in the minerals}

\section{Water-soluble $K$}

Seedlings decreased $\mathrm{H}_{2} \mathrm{O}$-soluble $\mathrm{K}$ in the substrate minerals from $3.00 \mu \mathrm{g} \mathrm{g}^{-1}$ (without seedlings) to 1.60 (Pisolithus XC1), 1.75 (Pisolithus sp.) and $1.50 \mu \mathrm{g} \mathrm{g}^{-1}$ (non-mycorrhizal) on average (Table 5). No differences were found in $\mathrm{H}_{2} \mathrm{O}$-soluble $\mathrm{K}$ in the 
Table 3. Mean concentration of $\mathrm{K}$ in residual culture solution and in sequentially extracted fractions of the clay minerals in vitro at fungal harvest

\begin{tabular}{|c|c|c|c|c|}
\hline \multirow[t]{3}{*}{ Fungal isolate } & \multicolumn{4}{|c|}{ K pool } \\
\hline & \multirow{2}{*}{$\begin{array}{l}\text { Culture liquid } \\
\left(\mu \mathrm{g} \mathrm{ml}^{-1}\right)\end{array}$} & $\mathrm{H}_{2} \mathrm{O}$-extractable & $\mathrm{NH}_{4} \mathrm{Ac}$-extractable & HCl-extractable \\
\hline & & \multicolumn{3}{|c|}{$\left(\mu \mathrm{g} \mathrm{g}^{-1}\right)$} \\
\hline \multicolumn{5}{|l|}{ Vermiculite } \\
\hline Control & 3.6 & 4.5 & 315.5 & 125.5 \\
\hline Pisolithus XC1 & 1.6 & 2.2 & 75.5 & 59.9 \\
\hline Pisolithus sp. & 1.8 & 2.5 & 153.3 & 76.4 \\
\hline P. microcarpus & 1.6 & 2.4 & 264.5 & 105.2 \\
\hline C. geophilum SIV & 1.6 & 2.3 & 163.4 & 62.6 \\
\hline \multicolumn{5}{|l|}{ Phlogopite } \\
\hline Control & 1.6 & 2.0 & 105.0 & 412.0 \\
\hline Pisolithus XC1 & 1.5 & 1.8 & 48.1 & 77.6 \\
\hline Pisolithus sp. & 1.5 & 1.7 & 45.4 & 225.2 \\
\hline P. microcarpus & 1.3 & 1.8 & 48.5 & 364.3 \\
\hline C. geophilum SIV & 1.4 & 1.6 & 53.0 & 210.5 \\
\hline \multicolumn{5}{|l|}{ Significance $^{\mathrm{a}}$ of: } \\
\hline Fungus & ns & ns & $* * *$ & $* * *$ \\
\hline K source & $* * *$ & $* * *$ & $* * *$ & $* * *$ \\
\hline Fungus $\times \mathrm{K}$ source & ns & ns & $* * *$ & $* * *$ \\
\hline
\end{tabular}

${ }^{a}$ By analysis of variance; ${ }^{* * *}, P<0.001 ;$ ns, not significant.

substrates following plant growth with or without fungal inoculation.

\section{$\mathrm{NH}_{4} \mathrm{Ac}$-exchangeable $\mathrm{K}$}

As shown in Table 5, both non-mycorrhizal and mycorrhizal seedlings markedly lowered $\mathrm{NH}_{4} \mathrm{Ac}$ exchangeable $\mathrm{K}$ in the two minerals. Mycorrhizal plants decreased $\mathrm{NH}_{4} \mathrm{Ac}$-exchangeable $\mathrm{K}$ more than did non-mycorrhizal seedlings.

\section{HCl-extractable $\mathrm{K}$}

Non-mycorrhizal seedlings depleted the $\mathrm{HCl}$-extractable fraction of $\mathrm{K}$ in phlogopite to a much greater extent than in vermiculite, and mycorrhizal seedlings lowered $\mathrm{HCl}$-extractable $\mathrm{K}$ in both minerals more than did non-mycorrhizal seedlings. Colonization with Pisolithus XC1 led to a greater depletion of $\mathrm{HCl}-$ extractable $\mathrm{K}$ in phlogopite by eucalypt seedlings than colonization with Pisolithus sp. but there was no such difference between isolates in the case of vermiculite.

\section{$\mathrm{HF}$ - $\mathrm{HClO}_{3}$-extractable $\mathrm{K}$}

After sequential extraction with $\mathrm{H}_{2} \mathrm{O}, \mathrm{CH}_{3} \mathrm{COONH}_{4}$ and $\mathrm{HCl}$, there was little difference between the blank controls (without seedlings) and non-mycorrhizal seedlings in residual $\mathrm{K}$ released by $\mathrm{HF}-\mathrm{HClO}_{3}$ digestion. Fungal colonization markedly lowered HF$\mathrm{HClO}_{3}$-digestible $\mathrm{K}$ in the minerals especially after inoculation with Pisolithus XC1 when vermiculite was the K source.

\section{Discussion}

Hyphal $\mathrm{K}$ uptake in pure culture was highest in the Chinese isolate Pisolithus XC1 and was also higher in eucalypt seedlings colonized by this isolate than those colonized by Pisolithus sp. The results indicate that this was due mainly to the effects of the fungus on plant growth, although $\mathrm{K}$ concentrations in the leaves of seedlings colonized by Pisolithus XC1 were also higher than those with the Australian isolate. Both fungal isolates were effective in promoting plant $\mathrm{K}$ uptake of mycorrhizal seedlings which was about twice or three times higher than in non-mycorrhizal controls. Our results are consistent with those of Burgess et al. (1993) who studied the effectiveness of 16 fungal isolates in forming ectomycorrhizas with E. globulus and $E$. diversicolor seedlings and found that only four of them (including $P$. tinctorius 2144 , here referred to as Pisolithus sp.) promoted plant growth and $\mathrm{P}$ uptake. 


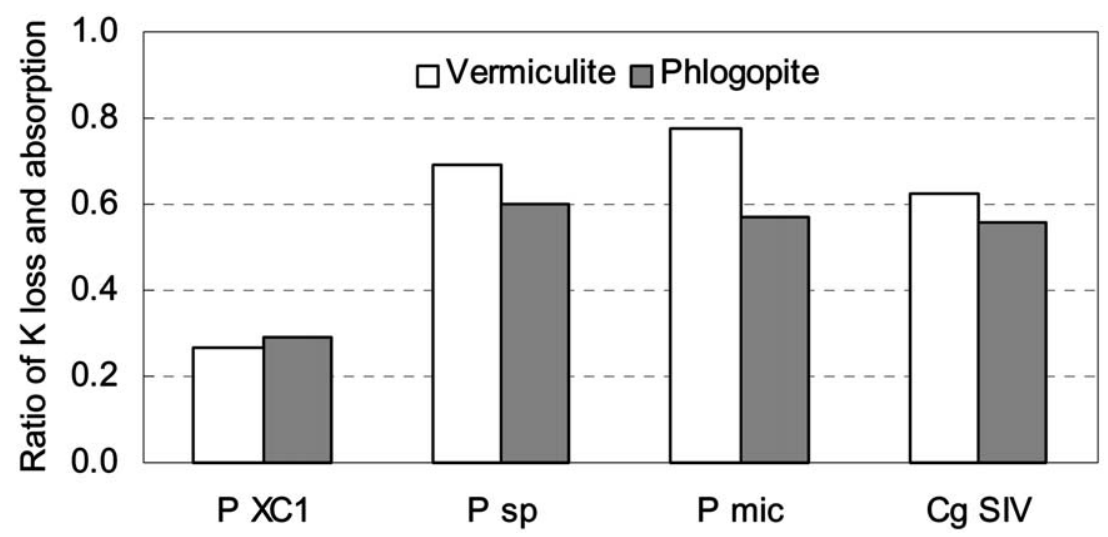

Figure 2. Ratio between the total amount of $\mathrm{K}$ loss from the substrate in each flask (K loss, including $\mathrm{K}$ in the liquid medium and water-, $\mathrm{CH}_{3} \mathrm{COONH}_{4}$ - and $\mathrm{HCl}$-extractable pools) and $\mathrm{K}$ accumulated in fungal tissues. P XC1, Pisolithus XC1; P sp, Pisolithus sp.; P mic, putative Pisolithus microcarpus; Cg SIV, Cenococcum geophilum SIV.

Table 4. Mean dry matter yield and $\mathrm{K}$ uptake of non-mycorrhizal and ectomycorrhizal eucalypt seedlings grown with vermiculite or phlogopite as sole $\mathrm{K}$ source

\begin{tabular}{lllll}
\hline Fungal isolate & $\begin{array}{l}\text { K source } \\
(\text { mineral })\end{array}$ & $\begin{array}{l}\text { Biomass } \\
\left(\mathrm{g} \mathrm{pot}^{-1}\right)\end{array}$ & $\begin{array}{l}\text { Root:shoot } \\
(\text { ratio })\end{array}$ & $\begin{array}{l}\text { K uptake } \\
\left(\mathrm{mg} \mathrm{pot}^{-1}\right)\end{array}$ \\
\hline Non-mycorrhizal & Vermiculite & 2.44 & 0.83 & 8.4 \\
& Phlogopite & 1.92 & 0.82 & 6.7 \\
Pisolithus sp. & Vermiculite & 4.36 & 0.72 & 16.8 \\
& Phlogopite & 4.24 & 0.75 & 17.0 \\
Pisolithus XC1 & Vermiculite & 5.60 & 0.80 & 23.7 \\
& Phlogopite & 6.36 & 0.75 & 27.6 \\
Significance ${ }^{\mathrm{a}}$ of: & & & & $* *$ \\
Fungus & & $* * *$ & $* *$ & $\mathrm{~ns}$ \\
K source & & $\mathrm{ns}$ & $\mathrm{ns}$ & $*$ \\
Fungus $\times$ K source & & $\mathrm{ns}$ & $\mathrm{ns}$ & \multirow{2}{*}{} \\
\hline
\end{tabular}

${ }^{a}$ By analysis of variance; ${ }^{* * *}, P<0.001 ;{ }^{* *}, P<0.01{ }^{*}, P<0.05 ;$ ns, not significant.

They also report that $P$. tinctorius produced the largest plant growth increases and the isolates that developed more extensive mycorrhizas on roots produced the largest growth responses, and isolates that increased plant growth also increased plant $P$ uptake. The finding that fungal isolates that are effective in enhancing host plant $\mathrm{P}$ uptake may also promote plant $\mathrm{K}$ uptake is also consistent with the belief (Smith and Read, 1997) that polyphosphate is stabilized by $\mathrm{K}^{+}$ions, and that both inorganic $\mathrm{P}$ and $\mathrm{K}$ may be transferred to the plant, thus maintaining charge balance in both symbionts.

Some tropical soils are rich in vermiculite, an expanded 2:1 type clay mineral (Mohr et al., 1972) and both $\mathrm{P}$ and $\mathrm{K}$ are commonly in short supply (Mohr et al., 1972). Under these conditions fungal inoculation may be important for the absorption of $\mathrm{P}$ and $\mathrm{K}$.
Mica is an unexpanded 2:1 type clay mineral and is a primary $\mathrm{K}$ mineral with $\mathrm{K}^{+}$ions adsorbed between the clay layers. Some of the $\mathrm{K}^{+}$ions in the crystal lattice, often referred to as lattice- $K$, are encircled by six oxygen atoms and expansion between clay layers is difficult. However, vermiculite has lower binding forces between mineral layers than unexpanded clay minerals (Huang, 2000). Thus, vermiculite subjected to $\mathrm{KCl}$-saturated treatment for one week contained three times as much exchangeable- $\mathrm{K}^{+}$as phlogopite, and $\mathrm{HCl}$-extractable $\mathrm{K}$ in vermiculite was only up to $30 \%$ of that in phlogopite in our experiment. In other words, if the same weight of the minerals is supplied, vermiculite will provide more exchangeable $\mathrm{K}$ and less $\mathrm{HCl}$-extractable $\mathrm{K}$ for fungal uptake than phlogopite. 
Table 5. Changes in sequentially extracted $\mathrm{K}$ fractions in the minerals after harvesting of the seedlings

\begin{tabular}{|c|c|c|c|c|c|}
\hline Treatment & $\begin{array}{l}\text { K source } \\
\text { (mineral) }\end{array}$ & $\mathrm{H}_{2} \mathrm{O}-\mathrm{K}^{+}$ & $\begin{array}{l}\mathrm{NH}_{4} \mathrm{Ac}-\mathrm{K}^{+} \\
\left(\mu \mathrm{g} \mathrm{g}^{-1}\right)\end{array}$ & $\mathrm{HCl}-\mathrm{K}^{+}$ & $\begin{array}{l}\mathrm{HF}-\mathrm{HClO}_{4}-\mathrm{K}^{+} \\
\left(\mathrm{mg} \mathrm{g}^{-1}\right)\end{array}$ \\
\hline \multirow[t]{2}{*}{ No seedlings (control) } & Vermiculite & 4.50 & 127.5 & 110.5 & 13.5 \\
\hline & Phlogopite & 1.50 & 100.5 & 385.0 & 35.0 \\
\hline \multirow[t]{2}{*}{ Seedlings non-mycorrhizal } & Vermiculite & 2.50 & 70.5 & 82.5 & 10.0 \\
\hline & Phlogopite & 0.50 & 65.0 & 345.0 & 31.5 \\
\hline \multirow[t]{2}{*}{ Seedlings with Pisolithus sp. } & Vermiculite & 3.00 & 47.5 & 40.5 & 6.0 \\
\hline & Phlogopite & 0.50 & 40.0 & 295.5 & 26.0 \\
\hline \multirow[t]{2}{*}{ Seedlings with Pisolithus XC1 } & Vermiculite & 2.75 & 50.5 & 40.0 & 2.5 \\
\hline & Phlogopite & 0.45 & 35.0 & 255.5 & 22.0 \\
\hline \multicolumn{6}{|l|}{ Significance ${ }^{\mathrm{a}}$ of: } \\
\hline Treatment & & $* * *$ & $* * *$ & $* * *$ & $* * *$ \\
\hline K source & & $* * *$ & $* * *$ & $* * *$ & $* * *$ \\
\hline Treatment $\times \mathrm{K}$ source & & $* * *$ & $* * *$ & $* *$ & ns \\
\hline
\end{tabular}

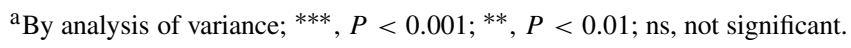

Potassium extracted by $1 \mathrm{~mol} \mathrm{~L}^{-1} \mathrm{CH}_{3} \mathrm{COONH}_{4}$ from soils is mainly adsorbed on the surfaces of soil colloids and present in the interlayer of expanded 2:1 minerals and is exchangeable. It is thus available to plants and could be also available to ectomycorrhizal fungi. In contrast, $\mathrm{HCl}$-extractable $\mathrm{K}$ consists mainly of interlayer $\mathrm{K}$ in unexpanded 2:1 type clay minerals and lattice $\mathrm{K}$ chiefly present in feldspars (Martin and Sparks, 1983, 1985; Mengel and Uhlenbecker, 1993), and is slowly released from soils and minerals. Numerous studies have indicated that $\mathrm{HCl}-$ extractable $\mathrm{K}$ in soils is often unavailable to plants in the short term (Brar et al., 1986; Grimme, 1974; Martin and Sparks, 1983, 1985; Mengel and Uhlenbecker, 1993). In a loess-derived soil (Luvisol), for example, $\mathrm{HCl}$-extracted $\mathrm{K}$ was not even depressed by ryegrass, a plant which usually has well-developed root systems and a strong ability to absorb nutrients from soils (Mengel and Uhlenbecker, 1993). However, $\mathrm{HCl}$-extractable $\mathrm{K}$ was markedly decreased by ectomycorrhizal fungi in our experiment. This may suggest that ectomycorrhizal fungi can utilize $\mathrm{HCl}-$ soluble $\mathrm{K}$ that is not available to plants and may explain why the $\mathrm{HCl}$-extractable $\mathrm{K}$ fraction was substantially depressed by eucalypt seedlings inoculated with Pisolithus XC1 and Pisolithus sp. compared with non-mycorrhizal controls. A similar observation was made in Douglas fir inoculated with Laccaria bicolor S238N (Huang and Lapeyrie, 1996). It is noteworthy that the pattern of reduction in $\mathrm{CH}_{3} \mathrm{COONH}_{4}$ - and
$\mathrm{HCl}$-extractable $\mathrm{K}$ fractions in the two minerals was different in fungal pure culture and fungus-root associations, indicating some changes in fungal $\mathrm{K}$ utilization and mobilization in the presence of the host plants.

After sequential extraction with water, $\mathrm{CH}_{3} \mathrm{COONH}_{4}$ and $\mathrm{HCl}$, the $\mathrm{K}$ remaining in the minerals may exist mainly in structural pools that are unavailable to plants unless the minerals are weathered. In the present work, however, 22 to $71 \%$ of the $\mathrm{K}$ accumulated in fungal hyphae was derived from structural pools (Figure 3) and this implies that weathering of the clay minerals and release of $\mathrm{K}$ from structural pools occurred in the fungal cultures. In eucalypt seedling culture, $\mathrm{K}$ obtained by $\mathrm{HF}-\mathrm{HClO}_{3}$ digestion after sequential extraction with water, $\mathrm{CH}_{3} \mathrm{COONH}_{4}$ and $\mathrm{HCl}$ was lowered very little (if at all) in the substrates of non-mycorrhizal seedlings compared to blank controls with no seedlings present. Fungal colonization significantly lowered $\mathrm{HF}-\mathrm{HClO}_{3}$-digestible $\mathrm{K}$ in the substrates. This indicates that that mineral weathering and $\mathrm{K}$ release may have occurred in the mycorrhizal seedling cultures and that ectomycorrhizal fungi may play a key role in mineral weathering and $\mathrm{K}$ release.

Both $\left[\mathrm{Al}\left(\mathrm{C}_{2} \mathrm{O}_{4}\right)_{3}\right]^{3-}$ and $\left[\mathrm{Fe}\left(\mathrm{C}_{2} \mathrm{O}_{4}\right)_{3}\right]^{3-}$ have very high chelation constants of $2.0 \times 10^{16}$ and $3.9 \times$ $10^{16}$. Oxalate may therefore chelate $\mathrm{Al}^{3+}$ and $\mathrm{Fe}^{3+}$ in the crystal lattice of minerals containing $\mathrm{K}$, resulting in weathering of these minerals and $\mathrm{K}$ release. Moreover, both protons and $\mathrm{K}$ are monovalent. The diameter of protons $\left(0.32 \times 10^{-10} \mathrm{~m}\right)$ is much smal- 


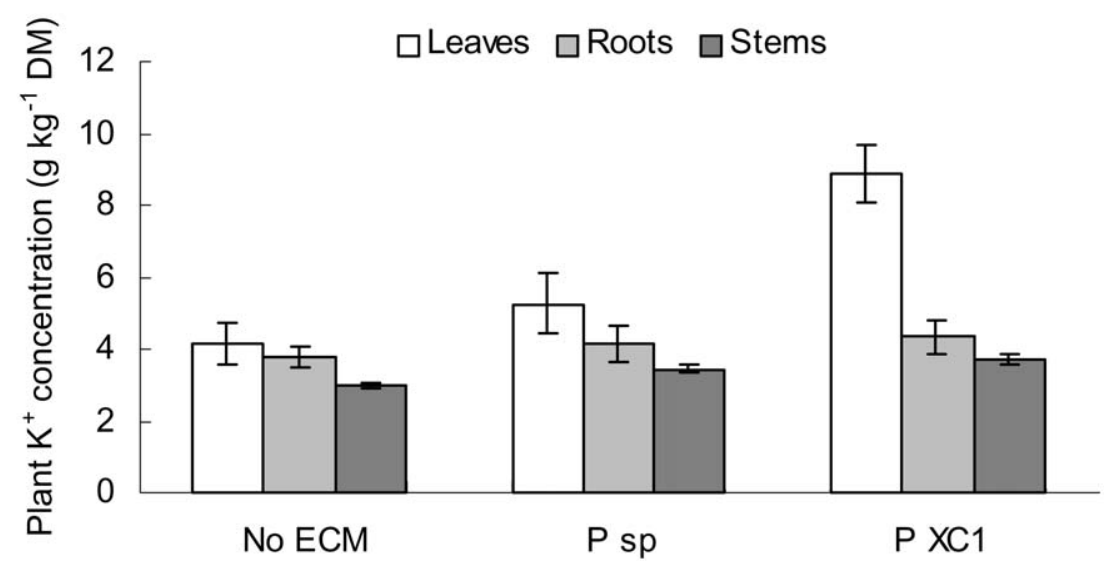

Figure 3. Mean concentration of $\mathrm{K}$ in leaves, roots and stems of non-mycorrhizal eucalypt seedlings and seedlings inoculated with Pisolithus sp. and Pisolithus XC1. Bars: \pm one standard deviation (SD). No ECM, no ectomycorrhiza (uninoculated control); P sp, Pisolithus sp.; P XC1, Pisolithus XC1.

ler than that of $\mathrm{K}\left(2.03 \times 10^{-10} \mathrm{~m}\right)$. Protons may therefore have a strong capacity to move through the interlayer of layer minerals such as mica and phlogopite and replace the $\mathrm{K}^{+}$present. The weathering of minerals containing $\mathrm{K}$ caused by oxalate and the replacement of the interlayer $\mathrm{K}$ by protons have been demonstrated, albeit not unequivocally, by stimulation experiments (Lapeyrie et al., 1987). Simultaneous depletion of $\mathrm{K}$ and $\mathrm{Mg}^{2+}$ in culture medium in vitro leads to enhanced weathering of phlogopite and this biological weathering is related to the efflux of protons and oxalate by fungal hyphae (Lapeyrie et al., 1987; Paris et al., 1995a, b, 1996). Minerals collapse and $\mathrm{K}$ release may occur through the formation of chelates of oxalate with bivalent and trivalent cations in crystal lattices. In addition, protons produced by fungi may move to the interlayer of expanded and non-expanded 2:1 type clay minerals to replace interlayer K (Cromack et al., 1979). Efflux of protons and oxalate ions by ectomycorrhizal fungi colonizing root surfaces could therefore be very important in the mobilization of interlayer $\mathrm{K}$ and structural $\mathrm{K}$ from minerals. In the present study, significant negative correlations were found between the reduction in $\mathrm{HCl}-$ extracteable $\mathrm{K}$ and fungal proton efflux $(r=-0.912$, $P<0.001)$ and between the ratio of total K lost in the flask to $\mathrm{K}$ accumulation in hyphae and oxalate efflux $(r=-0.890, P<0.001)$ under conditions of limited exchangeable K supply (phlogopite treatments). This suggests that protons and oxalate effused into the medium by ectomycorrhizal fungi under conditions of available $\mathrm{K}$ deficiency may replace interlayer $\mathrm{K}$ in clay minerals and lead to biological weathering of the min- erals and supports the findings of Paris et al. (1995a, b, 1996).

Trees in forests and plantations may interact with hundreds of ectomycorrhizal fungal species (Dahlberg, 2001). Studies are therefore required on the possible biological weathering of $\mathrm{K}$ from minerals by ectomycorrhizal fungi under field conditions. Experiments in boreal forests in which mesh bags containing sand and various minerals have been buried in forest soils of varying $\mathrm{K}$ and $\mathrm{P}$ status and examined after 17 months have indicated that ectomycorrhizas had a low potential to ameliorate $\mathrm{K}$ limitation by mineral weathering (Hagerberg et al., 2003). However, under tropical and sub-tropical conditions biological weathering of $\mathrm{K}$ could be more important and therefore merits investigation under field conditions.

\section{Acknowledgements}

This work was funded by the Natural Science Foundation of China (Project 39970139), the Chinese Ministry of Science and Technology (Project 2002BA516A17-05) and the Royal Society of London (Projects Q736 and 15360). We are also grateful to Professor F. Lapeyrie for the gift of three fungal isolates and to two anonymous referees for their helpful comments on the manuscript.

\section{References}

Blum J D, Klaue A, Nezat C A, Driscoll C T, Johnson C E, Siccama T G, Eagar C, Fahey T J and Likens G E 2002 My- 
corrhizal weathering of apatite as an important calcium source in base-poor forest ecosystems. Nature 417, 729-731.

Bowen G D 1973 Mineral nutrition of ectomycorrhizae. In Ectomycorrhizae, their ecology and physiology. Eds. Marks G C and Kozlowski T T, pp. 151-205. Academic Press, New York and London.

Brar M S, Subba Rao A and Sekhon G S 1986 Solution, exchangeable and non-exchangeable potassium in five soil series from the alluvial soils region of northern India. Soil Sci. 142, 229-234.

Burgess T I, Malajczuk N and Grove T S 1993 The ability of sixteen ectomycorrhizal fungi to increase growth and phosphorus uptake of Eucalyptus globulus Labill. and E. diversicolor F. Muell. Plant Soil 153, 155-164.

Chalot M, Javelle A, Blaudez D, Lambilliote R, Cooke R, Sentenac H, Wipf D and Botton D 2002. An update on nutrient transport processes in ectomycorrhizas. Plant Soil 244, 165-175.

Cromack K, Sollins P, Graustein W C, Speidel K, Todd A W, Spycher G, Li C Y and Todd R L 1979 Calcium oxalate accumulation and soil weathering in mats of the hypogeous fungus Hysterangium crassum. Soil Biol. Biochem. 11, 463-468.

Dahlberg A 2001 Community ecology of ectomycorrhizal fungi: an advancing interdisciplinary field. New Phytol. 150, 555-562.

Gerdemann J W 1974 Mycorrhizae. In The plant root and its environment. Ed. Carson E W, pp. 205-217. University of Virginia Press, Charlottesville, VA.

Grimme H 1974 Potassium release in relation to crop production. Proc.10th Congr. Int. Potash Inst., pp. 131-136. WorblaufenBern, Switzerland.

Hagerberg D, Thelin G and Wallander N 2003 The production of ectomycorrhizal mycelium in forests: Relation between forest nutrient status and local mineral sources. Plant Soil (in press).

Huang C Y 2000 Soil science, pp. 24-25. China Agricultural Press, Beijing.

Huang J G and Lapeyrie F 1996 Ability of ectomycorrhizal fungus Laccaria bicolor S238N to increase the growth of Douglas fir seedlings and their phosphorus and potassium uptake. Pedosphere 6, 217-224.

Jongmans A G, van Breemen N, Lundström U, van Hees P A W, Finlay R D, Srinivasan M, Unestam T, Giesler R, Melkerud P-A and Olsson M 1997 Rock-eating fungi. Nature 389, 682-683.

Lapeyrie F, Chilvers G A and Bhem C A 1987 Oxalic acid synthesis by the mycorrhizal fungus Paxillus involutus (Batsch. ex Fr.) Fr. New Phytol. 106, 139-146.
Leyval C and Berthelin J 1991 Weathering of mica by roots and rhizospheric microorganisms of pine. Soil Sci. Soc. Am. J. 55, 1009-1016.

Martin F, Díez J, Dell B and Delaruelle C 2002 Phylogeography of the ectomycorrhizal Pisolithus species as inferred from nuclear ribosomal DNA ITS sequences. New Phytol. 153, 345-357.

Martin H W and Sparks D L 1983 Kinetics of nonexchangeable potassium release from two coastal plain soils. Soil Sci. Soc. Am. J. 47, 883-887.

Martin H W and Sparks D L 1985 On the behavior of nonexchangeable potassium in soils. Commun. Soil Sci. Plant Anal. $16,133-162$.

Mengel K and Uhlenbecker K 1993 Determination of available interlayer potassium and its uptake by ryegrass. Soil Sci. Soc. Am. J. 57, 761-766.

Mohr E C G, van Baren F A and van Schuylenborgh J 1972 Tropical Soils. 3rd edn. Dordrecht, The Netherlands.

Paris F, Bonnaud P, Ranger J and Lapeyrie F 1995a In vitro weathering of phlogopite by ectomycorrhizal fungi. I. Effect of $\mathrm{K}^{+}$ and $\mathrm{Mg}^{2+}$ deficiency on phyllosilicate evolution. Plant Soil 177, 191-201.

Paris F, Bonnaud P, Ranger J, Robert M and Lapeyrie F 1995b Weathering of ammonium- or calcium-saturated 2:1 phyllosilicates by ectomycorrhizal fungi in vitro. Soil Biol. Biochem. 27, 1237-1244.

Paris F, Botton B and Lapeyrie F 1996 In vitro weathering of phlogopite by ectomycorrhizal fungi. II. Effect of $\mathrm{K}^{+}$and $\mathrm{Mg}^{2+}$ deficiency and $\mathrm{N}$ sources on accumulation of oxalate and $\mathrm{H}^{+}$. Plant Soil 179, 141-150.

Peng Z H, Feng J Z and Zhang S Y 1985 Handbook of Quantitative Chemistry. Beijing University Press, Beijing, China.

Schlecht G 1976 Nutrient uptake of plants and mycorrhiza. I. Ectotrophic mycorrhiza. Kali-Briefe Fachgebiet 20, 61-66.

Smith S E and Read D J 1997 Mycorrhizal symbiosis, 2nd edn. Academic Press, London.

Sokal R R and Rolff F J 1995 Biometry: the principles and practice of statistics in biological research, 3rd edn. pp. 332-334. W H Freeman and Company, New York.

Wallander H and Wickman T 1999 Biotite and microcline as potassium sources in ectomycorrhizal and non-mycorrhizal Pinus sylvestris seedlings. Mycorrhiza 9, 25-32.

Section editor: J.W.G. Cairney 